\title{
Questes
}

vestes Revue pluridisciplinaire d'études médiévales

11 | 2007

La transmission

\section{La transmission : introduction}

Valérie Deplaigne

\section{(2) OpenEdition}

Journals

Édition électronique

URL : http://journals.openedition.org/questes/553

DOI : 10.4000/questes.553

ISSN : 2109-9472

\section{Éditeur}

Les Amis de Questes

\section{Édition imprimée}

Date de publication : 15 mars 2007

Pagination : 3-6

ISSN : 2102-7188

\section{Référence électronique}

Valérie Deplaigne, «La transmission : introduction », Questes [En ligne], 11 | 2007, mis en ligne le 01

janvier 2014, consulté le 25 septembre 2020. URL : http://journals.openedition.org/questes/553 ; DOI : https://doi.org/10.4000/questes.553

Ce document a été généré automatiquement le 25 septembre 2020.

(c) Association des amis de «Questes » 


\section{La transmission : introduction}

\section{Valérie Deplaigne}

\section{NOTE DE L'ÉDITEUR}

Cet article n'a pas encore fait l'objet d'une autorisation de publication.

INDEX

Keywords : transmission, value, model, filiation, lineage, inheritance, heritage Mots-clés : transmission, valeur, modèle, filiation, lignage, héritage, patrimoine 